\section{CINEMATIC FORMS AND THE ASSEMBLY OF CITIES: BANGKOK INSCRIBED}

\section{Noah Viernes ${ }^{1}$}

\begin{abstract}
This article suggests that an aesthetics of contemporary urban life builds new avenues for treating the politics of visibility. Several reasons instigate this new approach. First, art forms illustrate and train a specific way of "seeing," a camera consciousness, that correlates with changes in the built landscape. A specific configuration, in other words, presents a relationship (an analogy) between the contemporary predominance of urban images and urban subjects that elude preexisting categories. These aesthetic departures can be illustrated by literary and cinematic "sentence-images" within the project that Jacques Rancière (2004; 2006; 2007) calls the "redistribution of the sensible." This paper's attempt to locate this redistribution according to the appearance of "the urban" in the literature of Prabda Yoon, Wanich Charungkichanant, Siriworn Kaewkan, Parinya Phiphathphorn, and two films by Apichatpong Weerasethakul, explains how Bangkok's aesthetic landscape is produced by its material "visible" form.
\end{abstract}

${ }^{1} \mathrm{Ph} . \mathrm{D}$. student in the Department of Political Science and Lecturer in the Department of Political Science and the School of Pacific and Asian Studies at the University of Hawaii at Manoa

\section{Landscape and the literary}

The more we were bound to the room, the more empty we became. And so we went out...

(Kaewkan 2006: 34)

There is an anxiety about the city that looms in several recent scenes from Thailanguage literature and film. The above passage taken from Siriworn Kaewkan's short story, "Our Resemblances," narrates a day in the life of one urban subject who leaves his apartment of "emptiness" to experience the material of the city. But as the subject leaves his room to travel across the landscape of Bangkok, the depthless urban signs and signifiers ultimately exacerbate this emptiness. In the story's final line, an analogy is drawn between the subject's emptiness and a frustrated sense of vision: "The more we try to open our eyes, the more blurry everything becomes" (Kaewkan 2006: 47). The dilemma of blurred vision inquires into how seeing is constrained by the landscape of the city, and what possibilities the forms of film and literature offer for addressing an urban subject alienated by a disinclination toward seeing. It is an understatement to say that academics do not turn to literature to understand the global city in all its irregularities of appearance.

The materiality of landscape is not only an immediate surrounding, and this is particular to a postmodern world: of media explosions, distances that are technologically compressed, and perpetual imagemaking that commodities lifestyles. As suggested in a recent conference program in Bangkok, postmodernism is like the city: both take the form of nostalgia for a rooted tradition, the schizophrenia of our dissipating material surroundings that acquire new meanings more rapidly than 
our ability to comprehend them, the rootlessness that positions the subject "at sea" in an ocean of imitations, and the hyperreal of so many places built upon simulated foundations (think simulacra). ${ }^{2}$ It is no longer intriguing that one may go to the zoo or even ice-skating on the upper-most levels of Bangkok shopping malls, or spend the majority of one's day inside a corporate tower that looks like an elephant, or that the "freedom" once yearned for in nature (e.g, with the Romantics, or Transcendentalists) is now signified by spaces inundated in concrete, exchange value, and vertical living). The zoo on the rooftop of Pata Mall, the Elephant Tower on Phahon Yothin Road, and the Sub-Zero ice skating rink at the Esplanade shopping complex, in these terms, are "real" places along the landscape of Bangkok. These contemporary dimensions of appearance can be equated with a sense of "seeing"; where even a highrise housing campaign in Bangkok is able to appropriate the slogan "I Am Issara" (I am Free) to equate the "freedom" of upward class mobility with a new fad in upper-level living. In each of these modes of seeing, which are thoroughly embodied by the urban landscape, the signified is increaseingly removed from the signifier.

This urban structuring of cultural forms means that a cinematic capturing of the everyday is increasingly related to a placebased dimension of vision. This article projects this dynamic by assembling film and literature in relationship to "seeing"

\footnotetext{
${ }^{2}$ Conference on Postmodern Thought and Contemporary Social Change (แนวคิดหลังสมัยใหม่ กับความเปลี่ยนแปลง

ในสังคมปัจจุบัน) at Chulalongkorn University, November 15, 2007, Bangkok, Thailand

${ }^{3}<$ http://www.charnissara.co.th/>
}

the urban landscape in order to show how new urban subjects relate to different kinds of development. Recent literary works (that more often than not mimic newer film forms) look for openings and fissures in what might be considered banal and localized activities, knowing the possibility of re-arrangement and contingent organization of life, as with the assembly of so-called "fictional" texts, vary in accord with a variety of possible scenes. Inside the frame of urban landscapes, literary texts provide a situated context which corresponds with a "point of view" directed through the avenues of the city's built form. ${ }^{4}$ To attend to a critique of "landscape" through its texts, according to the literary and landscape scholar John Dixon Hunt, is to illuminate "the very physical places where the characters, events and actions of literature as well as life are represented as taking place" (Hunt 2003: 123). This is why, I suggest below, that Thai language cinema and contemporary literary works provide an important contribution to our understanding of how the landscape of the urban city is constructed by a vision of it.

This approach of juxtaposing the cultural mediums of literature and cinema with the "affect" of landscape is not a new approach, but a way in which new "aesthetic" analogies might bypass old "disciplinary" categories. The analogy underpinned through appropriation of the term "aesthetic" refers to the existence of forms that call existing categories into question. If Aristotle's Politics or Poetics invoke two conventional categories for

\footnotetext{
4 " [T] he power of representing landscape is the power of the text, whether written, photographed, filmed or otherwise produced" (Crouch and Malm 2003: 259).
} 
two disciplines, then aesthetics can be construed, as the manner in which the existence of those categories is called into question. In this sense, the French Political Theorist Jacques Rancière uses the term "aesthetics" in opposition to representation, since the conventional visibility of the latter reinforces the dominant distribution of political visibility (i.e., through the existing categorical groupings: censuses, genres, canons, geopolitical labels, or the reductionist claims of "what belongs to what"). This "crossing" of fields has helped to multiply the applications of literature and the cinematic image.

It therefore seems appropriate that the work of Rancière, and particularly his interrogation of conventional poetic and political categories, surfaces alongside recent debates in comparative literature and film studies where distinctions between film and literary texts are problematized by "analogies." Literature is like film because of a historical lineage of illustration (Elliot 2003), and, conversely, film is like literature because certain film movements incorporated a meta-cinematic mode of "reading" that had originated earlier in the meta-text of the French New Novel (Kline 1992). In the analogy of the meta-cinema/text (or what one could call literary cinema or cinematic literature), it is the form that has become content, an increased attentiveness to an assembly of a scene. This assembly is political to the extent that it provides the ground of possibility for what can be experienced-e.g., in an opening establishing shot of Bangkok's seemingly infallible skyline in Pen-ek Ratanaruang's bixty 9ine (1999), or through an experiment in Surrealist form that begins in its navigation of the city in Apichatpong Weerasethakul's Mysterious Object at
Noon (2001). And beyond these filmic scenes, the landscape navigator resonates similarly in urban Thai literature. Rendering new epistemological high ground to the short story's use of montage, Siriworn Kaewkan inscribes a "navigator" from the top of a skyscaper, who engrosses the city with a camera-like birds-eye view and formulaically begins to list things in order to navigate the urban landscape as a microcosm of the globe. ${ }^{5}$ In each of these examples, elaborated more extensively below, form is content in the attempt to project, through the aesthetic assemblage, the political and economic hardships of a city affected by global narratives. This relationship between the cinema and the literary work, through the urban landscape's orientation of "seeing", is simultaneously a convergence between politics and aesthetics that informs the projection and visibility of the city in a variety of forms. Toward discussing these aesthetico-political analogies, Rancière, in his landmark work The Politics of Aesthetics (2004), begins with the following analogy:

If the reader is fond of analogy, aesthetics can be understood in a Kantian sense....as the system of a priori forms determining what presents itself to experience. It is the delimitation of spaces and times, of the visible and invisible, of speech and noise, that simultaneously determines the place and the stakes of politics as a form of experience.

(Rancière 2004: 13)

When Rancière refers to the "delimitation of spaces and times, of the visible and

\footnotetext{
${ }^{5}$ Kaewkan, Siriworn. 2004. "About a

Navigator on the Deck of the Baiyoke Tower."
} 
invisible," he is suggesting that there are all sorts of artistic forms in the city (among other places), but that some are unfairly (i.e., unequally) favored among others in order to represent what "spaces and times" should be. What can be experienced is directly analogous to aesthetic forms of "spaces and times," among which film and literature figure prominently. Rancière's three other closely aligned books to address the particularities of aesthetic forms are aptly entitled The Flesh of Words (2004), Film Fables (2006), and the cinematic The Future of the Image (2007).

The analogies that follow take the form of the city and align it with the form of both literature and cinema, an analogy that exemplifies "the place and the stakes of politics as a form of experience." In this sense, selected short stories by Siriworn Kaewkan, Parinya Phiphathphorn, and Wanich Charungkichornanth, treated in depth below, mirror the forms of cinematic presentation in Apichatpong Weerasethakul with regard to their formulaic and aesthetic approaches to the landscape of Bangkok. Each of these works, focalized through the form of the city, re-center Rancière's notion of the political, which he calls the "redistribution of the sensible," a ground for what can be experienced and talked about: a visibility conventionally resigned to the domain of film.

In the sense that film projects images, it does so through a sequencing or juxtaposition, or extended frames that invite reflection. A camera, in this way, thinks. Montage, one cinematic technique, works through the parallel juxtaposition of images (Rohdie 2006). If one looks at the relation between montage and literature, one finds that both undertake a similar form. The Thai language oeuvre of literature and film works with the materiality of urban imagery by asking how some images parallel other images (giving rise to analogies among films and everyday life or, below, between a scene at a site in Bangkok and an image invoked in a short story or film. These questions may, at first sight, seem trivial; for instance, in the relations between what a pedestrian or highrise resident sees versus the tracking landscape view of a passenger as framed by the window of an elevated train. But the relation the analogy invokes compliments one's knowledge of a generalized city with an added specificity of place. Here again, Rancière's work (2004: 12) wants to foreground these types of relations in order to visualize a kind of assemblage; i.e., "the distribution of the sensible":

I call the distribution of the sensible the system of self-evident facts of sense perception that simultaneously discloses the existence of something in common and the delimitations that define the respective parts and positions within it.

(Rancière 2004: 12)

This distribution of the sensible can be located in the landscape of the city because its visibility changes according to where a subject is positioned within it. Common views are orchestrated by common points of seeing. The visual documentation of films, then, exists alongside the textual commentaries of literature as a starting point, as everyday epistemologies, toward addressing the following question: what is an urban subjectivity; i.e., how does an urban subject navigate the space of the city through a transitional consciousness 
embodied by its changing surroundings? This article's attempt to answer this question looks not simply at the interiority of particular films; i.e., its narrative-laden content, but moreover at its assembly and form that aligns a variety of films and images with a surrounding material and literary landscape context. The subject is constituted through vision, as vision constitutes the landscape that positions the subject. This "visual subjectivity" allows for a redistributive notion of 'aesthetics' that realigns a view of the urban landscape through the literature and film that formulaically guide this view.

\section{Specificity of place}

Kublai Khan had noticed that Marco Polo's cities resembled one another, as if the passage from one to another involved not a journey but a change of elements. Now, from each city Marco Polo described to him, the Great Khan's mind set out on its own, and after dismantling the city piece by piece, he reconstructed it in other ways, substituting components, shifting them, inverting them.

(Calvino 1974: 43)

The urban politics of film form is, in the vein conceptualized in Rancière, an aesthetic which often crosses between the spheres of art, literature, photography, and music for direction. A movement to the city can be interpreted as a natural progression, since it is the predominant site for the subject's unavoidable encounter with more than one of these spheres at the same time. At the threshold of aesthetic spaces, the urban subject is then forced to think through a plentitude of signs, screens, soundtracks, noises, and social texts that compliment their encounter with "art" forms. Seeing is inflected by sounds, smells, and other sensory flows. In this intertextual-aesthetic sense, Marco Polo, the urban navigator of Italo Calvino's Invisible Cities (1974), reflects on his manner of "looking" at the city, "dismantling the city piece by piece...reconstruct(ing) it in other ways," which is a cinematic means of encountering space-where the possibilities of encounter are never truly exhausted. Cities are not merely mapped or built, he suggests, but are simultaneously thought and imagined. Siriworn builds on this cinematic rendering of space. The protagonist in "A Navigator on the Deck of the Baiyoke Tower," rips areas of a map of the world in order to reconfigure the cartographic relations between East and West and the possible horizon of thought, but all this takes place from a raised view of the city. The city is not simply global and generalized, but constituted by a geopolitical image that renders its own specific relations.

If the inquiries about 'form' and inter-art analogies draw a relationship between literature and the cinema, how does Bangkok project this analogy as a 'distinct' place with its own singularity constituted by a pluralism of social forces? Numerous problems begin to emerge with this dilemma of global difference. If cities are thought and imagined, and cities are "globally" networked, and if a kind of postmodernity thrives off imitation through the construction of similarity, how does one articulate the specificity of an urban landscape? Toward this specificity, film manages to project an archive of images (which contain a subset of combined sequences) that can be read and reassembled with varied results. Rancière (2007: 46) suggests that literature too 
surfaces as cinematic in a "linking" sense, through a combination of sentenceimages. It is the sentence from a novel, the character on-stage, as well as the film that express these sentences. It's not that sentence $=$ sayable, or that image $=$ visible, he continues, but the question of how the relationship between the text (that links actions) and the image (that imparts presence and substance) link together. Two primary events unfold through these links: the sentence-image establishes a phrasal power of continuity, while projecting an image that contains the power of rupture. One might picture a carefully constructed poetic bomb dropped upon established category of narrative representation and this is the power of analogy. "The sentence-image" so far as it hangs together with a variety of contemporary moments, instances, and dimensions "must make its music heard" (Rancière 2007: 58) as it re-distributes what can be experienced. In a literary sense, the images conjured up in any sentence train the visual imagination and produce sensible affect. Something about a situation, an assembly of elements, resonates more than simple character monologues that fit into a larger narrative. If representations of the majorities stifle the stories of the others, and if representation is a mode of generalizing, the specificity of the city calls for a more affective and resilient sentence-image: "where language is nothing more than intensities...a kind of "minor music", (Deleuze 1986: 26). "The sentence-image" says Rancière "must make its music heard" (Rancière 2007: 58).

It is appropriate that Rancière's concepttion of the sentence-image should undertake musical qualities as its primary metaphor. The city, after all, contains images that can be linked through these aural objects. Does writing, like cinema, not presuppose a soundtrack, an interior rhythm that facilitates the manner in which its parts hang together? Further, if the relationship between sound and image is presupposed in the cinema, could the importation of sounds in literature collapse conventional distinctions between these two art forms? Music acts as an analogy between these forms, an aural motif to enhance the specificity of the city, finding itself below in the redistribution of particular places and times.

Prabda Yoon's cinematic short story Probabilities (2000) springs to mind, in terms of how it deals with time and the merging of the elements of cinema. During each of the Friday night film screenings held at the house of the story's protagonist, the grandmother assumes soundtrack duties by playing Mozart's Violin Concerto No. 5 and Symphony No. 41 in the background regardless of what movie is being screened. This simple "sentence-image" of Prabda Yoon conveys its music in several ways: in its description of musical taste outside of a nationalcultural register (a tendency of the "Orientalist" project), as a conceptual means to activate the memory of the protagonist, as a foregrounding of the cinematic elements of soundtrack that guide images and, most importantly for this analysis, as the surfacing of the contemporary tendency to think and write in the language of cinema.

Beyond the dimension of writing lies the additional layer of everyday experience, i.e., as a mode of reading the city. Following the above treatment of Rancière's work, each of these readings of the city privilege the ground of what can be experienced as a visibility, as an aesthetic assembly of parts. The parts of 
the city are not unlike the parts of film, containing soundtracks in as much as they contain fragments of technological advances embodied by the urban condition. With these fragments in mind, films and literary works nod toward the streets of Bangkok, to the everyday, and to its composite "layers" that foreground the analogies of the city: in travels between music, text, dialogue, and image. How many screens does one pass in a day? Could one not pass through a montage of billboards, while sharing SMS photos and hyper-real video captures (not unlike those used in recent films like Soraya Nakasuwan's Final Score (2006), or in Chukiat Sakveerakul's reality-showmimicking 13 Beloved (2006), where the rules of new technologies dictate the actions of the characters)? Again, beneath the images lies a soundtrack, where even those who can usurp the soundtrack freedoms of an iPod playlist can still be held victim by the amplification of Siam Square's networked speakers, each constraining the possibilities of an experience of place. A distribution of place is an assembly of parts that hang together, of fragments that find their manifestations not in representations of a coherent whole but in its opposite: as a sequence of fragments. No city can be the same. In this light, a Rancièrian approachs to sensibility connect the everyday life encounter with the city as more than simply a succession of images that combine time and space. Instead, the configuration of elements conspires to perpetuate a variety of moods. Seeking to understand these moods and their connection to the city, a kind of reading, requires close attention to how the phenomena of its form is amplified (i.e., externalized). The increasing role of Modern Dog songs in recent Thai films underscores the point. For example, the song Korn in Wisit Sasanatieng's Citizen
Dog undertakes a Greek notion of the chorus as the organic fabric of the city, while the song Ta Sawang 'Bright Eyes' inspires the character Peur from Final Score (2006). In the latter case, the lyrics ท้องฟ้าแสนจะกว้างใหญ่ หนทาง ยังคงยาวไกล ('The sky is the limit, but the path is long') run parallel to the intensity of the impending college entrance exams, but also to his contemporary status within an urban chorus. Final Score is weaved together through landscape shots of the city, movement through the city, and an amazing diversity of songs. The city's distribution of experience, through an implicit fluctuation of sensibility (of the rhythms of music, depression, celebration, and even weight loss), underscores a certain anxiety left for the arts of cinema and literature to address.

It is precisely these anxieties, caught within the movement and assembly of the city, that drive the unproblematic whole into the eventuality of rupture, critique, fragmentation, and eventually, the movement of forms against representation. It is this convergence of meta-levels (i.e., of visible forms in a particular work), of language and an 'everyday reality,' that critics like Patricia Waugh (Cobley 2001) explain through an "increased social and cultural self-consciousness" (Rancière 2007: 173). But Rancière wants to say a difference is always 'there,' beyond the delimitation of times and spaces, and that this departure from narrative representation (away from a particular distribution of parts) is what is conveyed by the 'aesthetic.' The politics of aesthetics is thus, in this case, what literature and film can do to "confront the established order of identification and classification" (Rancière 2004: 89). The departure of a realignment of fragments that redistributes the sensible is largely 
responsible for a new specificity of the city.

\section{Camera-consciousness and the configuration of the city}

The sentence-image epistemology that gives rise to the projection of the city deviates from the attempt to clarify the meaning of a particular narrative. The sentence image would rather illuminate, i.e., render visible, the composition (i.e., the parts or "the aesthetic") of the city. This projection of "sight" is made possible through a mode of thinking oriented by a passive camera. Below, I refer to the alignment of landscape, movement, and subject as productive of a cameraconsciousness. How the camera thinks is how the subject relates to, and is conscious of, its surroundings (Branigan 2006).

The life of the camera was always related to the development of the urban landscape, according to film theorists like Béla Balász (2004). Balász uses the camera of the silent film as his starting point for this argument since the camera could capture what the subject might have missed. It is the camera, he suggests, that is endowed with the power to teach the viewer "to see the intricate visual details of life" (Balász 2004: 315). Facial close-ups, with the technological advances of modernity that packed people closer together, were urban events in an everyday context. The camera close-ups that Balász compared to the sight of two rush hour subway riders is an analogy raised with regard to how urban infrastructure positions the subject's field of view in the city. Balász suggested that both the industrialization of cities that facilitated constrained close-up contact through trains, subways, buses, and other ephemeral and transitory spaces, gave rise to the situations projected in the camera dimensions of visibility.

Balász's treatment of a camera-consciousness inflected by urban space helps to clarify the relationship between Rancière's sentence-image and the material of the city. The building of tracks, rails, pathways, sidewalks, and other routes through urban space entails quick cameralike movement through a variety of visual shots as different times and spaces converge and as frames run through a variety of sequences and successions. The parts hang together. Phrases and images become linked. Montage, "the joining together of different elements of film in a variety of ways, between shots, within them, between sequences, within them", is the keyword here since the numerous possibilities of presentation lend to "the possibility of the reworking of reality in images, a possibility of transformation, of creating new realities and new thoughts, rather than accepting existing ones" (Rohdie 2006: 15, 59). In any image capturing the vertical layers of Bangkok's Victory Monument to invoke one example among many others, there are multiple fields of view rendering several ways of "seeing" such that a camera consciousness can be interpreted in terms of three camera dimensions.

At the highest point of modern Bangkok transportation (and this highpoint refers to class, technological, and visibility dimensions), the Skytrain produces tracking long shots of the city, and in this case, a center guided by its actual track. Inside the Skytrain, simultaneous close-up to medium shots are common, a montage of passengers who are visible to each other. To the rightward position of the foreground, pedestrians encircle the Victory Monument as they walk along the 
raised sidewalk. Their vision takes the form of long-shots also guided toward viewing the monument. While the previous two levels suggest the raised level of vision in proportion to the construction of the city, the lowest level, comprised by buses and automobiles, gridlocked within the confines of urban development's organized chaos, remains at street-level. Depending on the direction or confinement of the street-level position, a subject's camera consciousness deviates between panning, tracking, and worms-eye view shots. The landscape directs vision. Contemporary urban travel can be construed as a montage of camera shots where windows, walkways, and elevated train tracks constitute the frame and the very possibility of sight.

The travel from one level of "seeing" to another is itself contained within a literary and cinematic archive. The roundabout that looks a lot like the traffic of the Victory Monument's surrounding circle is projected in Wanich Charungkichananth's The Capital (1991) where a sidewalk worms-eye view leads into a bus interior, an encounter with those who share the narrator's mode of "seeing." From the bus window, this is how the narrator sees:

Edging into the intersection's roundabout, the bus jerked forward at random. Bumper to bumper, and continuously bottlenecking, an assortment of cars crowded together as they entered the traffic circle. Cars and taxis overlapped each other, both stuck, confused, and unwilling to allow space to the other. Disordered, I hung on to the rails as the bus struggled to pass through the roundabout. Leaving behind the chaos, another sticky situation awaited at the next four-way intersection.

(Charungkichananth 1991: 36)

This traffic condition lasts for approximately 30 minutes, according to the unnamed male narrator. During those 30 minutes the reader learns of his exhaustion and physical weakening due to crowds scrambling toward the bus entrance, and the smell of sweat within a bus growing increasingly hot. Like many works of literature that project the relationship between alienation of the subject and the ruthless grip of modernity (as in Jean Paul Sartre's Nausea or Albert Camus' The Stranger), the mounting nausea of the narrator exacerbates the tension of the story using the bus as a laboratory for measuring the visible world. An hour passes. The narrator moves further back to the rear of the bus. The exterior tracking shot of the traffic circle in the above passage is followed by a further entrenchment into this world he calls Hell: the bus remains a constrained space of vision. A move to the depths of this world, i.e., to the back of the bus (with windows fogged from humidity caused by the outside rain), turns the frame of narration to the interior close-up:

Ugh...I groaned in my heart that the bus would move a bit but to no avail. There were 7 people sitting next to me in the rear of the bus. I observed each of their eyes thinking that there couldn't be anyone feeling any different than me.

(Charungkichananth 1991: 41)

"Observing each of their eyes," the above passage suggests the narrator's identification with the other bus passengers sitting along the back row of the bus. This 
empathic moment of affinity is made possible by a close-up oriented consciousness of interior surroundings, since observation is facilitated by proximity. The story progresses with descriptions of other passengers sitting along the back row, peering through the window frame to observe the technological fall-out of a broken-down car, then cutting back to the interior where his observation reveals faces devoid of emotion: "The people in the bus where I was appeared as faces devoid of feeling" (Charungkichananth 1991: 43).

Vision comports with a notion of equality brought into space through the aesthetic arrangement of parts within the scene of the short story. Because the subjects of the bus "see" similarly, they are affected in common moment. But it is the soundtrack of the story that allows this moment of equality, among those without a voice, to be rendered visible. The moment of tension reaches its boiling point, where the clichés of genre tend toward more conventional turns. As a departure from the filmic genre, The Capital projects a cinematic technique in musical soundtrack, since there is nothing worse for the narrator than the alienating condition of the bus, gridlocked and collectively devoid of communication. Up to this point, the story is a story of vision progressing through the images of the narrator in place of any dialogue between characters. Like the film underpinned by a soundtrack, The Capital manages to make its music heard through a sentence-image. The sounds of country music suddenly emerge from an anonymous passenger as the narrator is sincerely moved by a $l u k$ thung voice that morphs an anonymity of characters into kindred souls.
The reader recognizes the place of the song, a diversion through urban space to the migration routes of the poverty stricken northeast that brings workers to the city: the Isan region of Thailand. As the young Isan man continues to sing, the narrator smiles so the spontaneous singer would notice the narrator's endorsing gaze. The relationship becomes one between the elements of text, image, and soundtrack rather than a dialogic union between characters. The scene becomes more than an empathic moment, but one of vision ignited by sound. The cinematic story of The Capital is the story, following Rancière, where a redistribution of the sensible is made possible by a reassembly of urban parts tied to the landscape of the city.

If Wanich's story demonstrates several modes of a subject-oriented camera consciousness from the street-level of the bus, other contemporary stories project the increasing verticality of vision. The distance of the image parallels the distance between appearances and realities in contemporary fiction. In Parinya Phiphathphorn's "The Next Station Is..." (Phiphathphorn 2002) the writer prefaces a story told through the Skytrain's movement through the city with a comparison of Bangkok to New York City, London, Paris, and other cities, "in the way I've seen them in movies" (Phiphathphorn 2002: 82). Bangkok is an appearance, which will be narrated, for the most part, from the elevated level of the Skytrain's interior. The story starts from Mo Chit, a place once known as a transitional link between Bangkok and the outer Thai provinces, but now a base of technological advancement and the entry point for passengers with cell phones, notebook computers, and the latest fashions. The fashion of appearance 
saturates the story as the reader arrives at the hip area of Phrom Phong where a woman, noticing a man reading a book by Earnest Hemingway, asks him if he's a writer-an assumption she arrives at via appearances. The visual layering of the scene is carried further when the narrator describes the same "Thai" woman by her "appearance," as one who might be confused as a foreigner. The man who's reading Hemingway doesn't actually like Hemingway's books, but envies his lifestyle. His reading is dictated by appearance and the anticipation and normality of one consuming an image. But appearances never equate with their referent, which is adequately conveyed when the woman departs leaving her male acquaintance with a name card reading "Moon Hamingway." The American writer had a nice last name, she thought.

This relationship between appearance and the imagination facilitates a relationship between the reader and the mapping of the city within unstable global and cartographies. When the cartographic relations of the city seem fixed, as in the categorizing of places through maps, the succession of film-like sequences written in contemporary Thai literature insinuate new distributions of the sensible. Siriworn Kaewkan's A Navigator on the Deck of the Baiyoke Tower (2004), like "The Next Station Is...," presents the sentence-image with an incomparable set of differences in "seeing" that has unfolded since The Capital. This mode of seeing, apart from a title that suggests a ship and an ocean (the Thai word for "navigator" conjoins the words "knowledgeable-traveler-ship"), begins on the top of the tallest skyscraper in Bangkok. Its opening shot projects the following scene:
Having entered the Third month the aged Srimin sat that way from daybreak until 9 o'clock, smoking one cigarette after another, in his favorite chair, on the deck of the Baiyoke tower, in the middle of Bangkok, sipping on black coffee, staring at the illumination of sunlight, sinking into silence, waiting for the arrival of daybreak.

(Kaewkan 2004: 55)

Siriworn manages to instill the story with sequences, like lists and successions of images, but also with a sense that seeing is proportional with a positioning, a setting that enunciates the possibilities of vision. This mode of seeing is trumped by an imagination that in turn relocates the horizon or the possibilities for vision. Srimin, the sole character of the story, is an old man who seems to draw many of the morning's thoughts from idealized voyagers of the past, places of discovery, and a variety of cartographic relationships between East and West. Further into the story, this relationship between East and West becomes increasingly problematic, especially as it appears on the global map. Srimin, sitting at the top of a skyscraper in the center of Bangkok, must embody the navigator he aspires to be, but, lacking in actual sight due to old age, his imagination is projected through a series of fragments. Navigators: Vasca de Gama, Marco Polo, Captain James Cook. His immediate surroundings: "the prayer call of the Muslim community and the sound of the Cuckoo's song came floating through the air." The horizons of East and West: Viking, Magellan, New Horizon, The Bible, The Indian Ocean, Malacca, Constantinople. Also the time dimension of these fragments: "It's set." He thought, "I'll begin my preparations. The East. The 
humble Mekong. The Mekong river. The building fronts blinking: $1 \ldots 2 \ldots 3 \ldots 4 \ldots$. The climactic moment arrives as he rips the confusing world map along old borders to proclaim new horizons:

Then he suddenly jumped up from his chair, clashing with the coffee table, lifting his hands to embrace the sky, raising his head to the sun at dusk while shouting:

"The East! The East!"

Then silence and stillness ensued.

Then he lit another cigarette.

Then he grabbed a world map and lifted it once more as though his eyes could see without difficulty.

Then he ripped the world map, separating Europe and America along the Atlantic Ocean bringing the parts along the Bering Strait into alignment.

The illusion emerging from the map was significant, the aged Srimin thought, but its conjecture was villainous.

(Kaewkan 2004: 63)

There is something different in "looking" and "encountering" space between streetlevel, the interior of a bus, or the elevated area of the landscape, Bangkok's Skytrain or the city's tallest skyscraper. The more "multiple" our field of view is, the more camera-like our perception becomes. But as Parinya Phiphathphorn's story demonstrates, a field of view still can be saturated with images removed from their material foundations, i.e., as mere appearances. Siriworn seems to suggest through the character of Srimin that these appearances must be renegotiated through the active reimagination of a horizon. This is possible, not only through the character's position, but through the author's arrangement of figures and intensities that re-map the landscape. And what we find is that if Wanich's The Capital set the frame in motion, through an ethical encounter facilitated by a cinematic mode of seeing, more recent literary works have undertaken such frames as a relation among parts that hang together, as opposed to people as parts that either belong to the same group or that happen to be in the same place.

More obvious examples in contemporary Thai literature run rampant. Win Lyovarin's The Lover (1999) takes montage as its formal technique, each phrase (an image) separated by a forward slash (/) to signify the need to renegotiate meaning at each turn. In Anusorn Tipyanon's London and the Secret in the Kiss, the narrator presents his memoir of 9/11 by referencing Danis Tanovic's contribution to the short film collection $11^{\prime} 09^{\prime \prime} 01$ (2002), a film that focuses, like Anuson's memoir, on proximity to the event rather than a moment along a historical trajectory. And, perhaps a surefire classic, Parithat Hutangkoon's เพลิงรัก ลานแค้น 'Flames of Love, Grounds of Regret' (2002), fools the reader along with the narrator, into digesting an illusion as the real as our captors (a film crew) stage the hold-up of a shopping mall in order to capture a more real depiction of distress. The story assumes the cinematic technique of misc-en-scene as its modus operandi rather than conventional narrative techniques. And finally, the example most often incited in response to this article's aesthetic claim, Chart Korbjitti's short 
novel Time (1993) demands attention to a film's vocabulary of shots in order to understand the narrator's visual mode of rethinking human relationships in the context of older art forms.

Films, like their presentational counterparts in literature, cannot avert the material foundations that comprise the construction and composition of the city. The camera consciousness of a film enters the camera consciousness of a subject which initiates a point of recognition with one's material surroundings. The encounter with the city, the horizon of the contemporary, is recognition perpetually re-oriented. If literature becomes increasingly cinematic with a development-led shot orientation, the cinema as treated below becomes increasingly literary in order to find different ways of "seeing" the landscape.

\section{The city as mysterious object}

The city seen through the lens of a camera consciousness appears unlike a map that fixes objects into a particular time and place as a particular distribution of the sensible. The camera breaks things into pieces, rendering the unity of a whole into a mysterious object perpetually fragmented and into new horizons of thought. Attending to this horizon of thought, a distribution of sensible experience within the larger spatialized urban object, the city is projected, which is to say "distributed," through the cameraeven in the provinces in the consciousness of a rural food vendor or in an urban landscape photograph that projects the development of a new provincial city. The city is born not simply out of the physical construction of tangible materials like skyscrapers, but through an ontology of everyday life that is more pervasive than any delimited geography: a desire. The films treated below suggest a configuration of this ontology in accord with spatial designs, temporal rhythms, and images that break with a demographic text. ${ }^{6}$ This assemblage, an aesthetic way of reading the contemporary as an urban phenomenon, moves the film viewer into an engagement with the images that construct a desire of the city. This urban desire, embedded into the landscape, accounts for the way the city is experienced in the two films treated below.

In this urban-navigational sense the first feature film of Apichatpong Weerasethakul entitled Mysterious Object at Noon (2000) constructs the city as an "object" fragmented through transient points of view which change based on the multiple fields and levels that affect these views. Shot between 1997 and 1999, Mysterious Object takes its title from a more melodramatic feature shot decades earlier, only this film is one of departures and genre transgression, a mixing of intertextual elements of the national landscape. But its journey, a formulaic experimentation with the Surrealist technique of Exquisite Corpse, begins in

\footnotetext{
${ }^{6}$ The event, the encounter, and the possibilities of experience become controversial as they exit "national" forms of representation. Hence, the issue of censorship, nationalism and the artist's role in shaping national "graphics" constitute a political problematic. But to clarify this issue of "demographic" as a political question, one need only look at its etymological character:
}

$\delta \varepsilon \mu \mathrm{s}=$ demos $=$ people $/ \gamma \rho \alpha \varphi \circ \varsigma=$ graphos $=$ write

Michael J. Shapiro (2004), in this vein, writes "[t]he nation-state is scripted" (49). 
Bangkok at street-level and ends in the more peripheral areas of the Thai provinces. His next two features Blissfully Yours (2002) and Tropical Malady (2004) avoid Bangkok altogether in order to confront what some might describe as landscapes unique to the outer Thai province. His latest feature Syndromes and A Century (2007) returns to Bangkok in its final half in order to deal with what few film critics seem to notice: the development of the construction of a landscape and a camera consciousness that encloses and manipulates contemporary human life.

Apichatpong's films are about "seeing," and often attempt to convey what is beyond vision through affectations and the subtle movement of a camera, the heightened soundtracking of non-human surroundings, or the accentuation of simple moments in time that most exemplars of urban studies might take for granted. In Mysterious Objects, "seeing" unfolds in a manner which suggests that images are already pre-configured into the mind of the narrator so that when each person attempts to tell the primary story of a character named Dogfahr, subtracted of any narrative criteria, the images change according to the experiences of each storyteller. Even as the story departs from the city, the projected images can not escape the urban development that gives rise to media shows, Kentucky Fried Chicken, the import of Manga comics into Thailand, the prevalence of melodrama, the centrality of military announcements, the cultural hierarchy that enables foreigners to prosper in Thailand, and so on. A message about the city resonates: comics, fast food chains, military rule, and the foreign wielding of power operate most prevalently in the city.
But the form of the film is itself a treatise on how the forms of the city figure into multiple ways the subject is embodied by it. The opening credits, for instance, read "conceived by Apichatpong Weerasethakul," rather than "directed by Apichatpong Weerasethakul" since cities, according to the objective camera, escape any single point of view, i.e., any one representation willed by the director. The opening frame of Mysterious Objects is a departure from the closed story form or representation and towards the aesthetic redistribution of the sensible underscored above. This redistribution is made possible by the disorder of the city and the distribution of multiple points of views facilitated by it. The form of the city, the mysterious object, is reoriented via the possibilities of the camera's cinematic world.

How does the city amount to a world and how does this world work? Apichatpong's production company, Kick the Machine, tells us that the stories that comprise different narratives within this film are the "Villagers of Thailand." Each person who attempts to tell some fictional stories of a character named Dokfahr is "in another city" narrating the relationship between a boy and his teacher. The story departs from several elements of representation, the distribution of the sensible object of the city, in order to address the assembly of that object. Plot, characters, language, and spectacle construct the object, Apichatpong demonstrates, but it is desire that holds this particular distribution of objects in place.

The film begins to address this objectification of the city with a departure from Plot. The opening intertitle "Once

\footnotetext{
${ }^{7}<$ http://www.kickthemachine.com/works/mist erios_object_at_noon.html>
} 
upon a time..." signals the most conventional means of opening a story. But as an intertitle, followed by the black and white shot of the city from a moving vehicle, time has been destabilized and the development of the city turns both mysterious and monstrous. An urban street vendor, the viewers first encounter with anyone resembling a character in this film, tells her story of being sold into prostitution, but is then asked to begin another story that may be either "true of fictional." Only a few minutes into the film, the audience is invited to pursue not simply what brings one to the city, but the ways in which the city will inform their narration of a story.

The characters of the film are pulled from the yoke of representation because of the spontaneous manner in which these "real" people actively engage the story in innovative ways. "So I was residing in this floating object..." one elderly woman begins as she attempts to explain Dokfahr's disappearance. This character belongs to a succession of scenes that likely occur outside of the city, but a repetitive return to urban scenes of "exterior characters" (of producers, editors, those who discuss ideas for the film we are watching), prefigures a difficulty in escaping the city. A desire positions the city, however distant one deviates from it.

If the city cannot be escaped, it is because a mode of thinking, the camera consciousness of the urban subject, exists even in the imagination of the rural vendor. In this way, the camera's documentation of life in the provinces engages a rural food vendor's image of the city. "If it's in Bangkok, you will get paid more than this. A Pain-reliever company will sponsor you." In a proceeding scene, two young students use sign language to signal the phrase "she sang and danced beautifully" in which the character of Dogfahr takes the form of beauty contests transmitted on evening television. In Mysterious Object at Noon the camera follows the imagination which, in many cases, is tied to some aspects of the urban spectacle. Spectacle requires vision, a mode of seeing, but thought imagines something beyond mere representation.

Engaging the urban spectacle means projecting the relations of vision. When a group of men are filmed watching a Muay Thai match, the fighters, the actual spectacle, remain absent from the frame. Instead, the camera captures the act of seeing on the part of the audience. This might be one of the most explicit sequences of the film as a montage of groups surrounding the Muay Thai ring are captured in a succession of images. Here again one notes the assemblage more than a representative play of expectations. A distribution of the sensible, of what can be experienced through a particular delimitation of times and spaces, is called into question by a "seeing" and thinking that makes the city possible. A desire for the spectacle of the city, Apichatpong suggests, is more interesting than the spectacle itself.

The projection of urban desire has become increasingly prevalent in recent Thai films. The relationship between the construction of the city and the desire of the city becomes one way of understanding Apichatpong's Syndromes and A Century (2006). It shares two primary correlations with Mysterious Objects at Noon that are significant to this analysis. First, the Thai landscape is built into the process of "looking" that visualizes the relation of desire to the city. Secondly, the final half 
of the film signals his first return to the city since Mysterious Objects at Noon.

\section{Urban aesthetics/landscape montage}

Fifty-three minutes and thirty seconds into Syndromes and A Century, a director leads subjects (you, I, and the rest of the world) into the city. Having departed from a provincial world explored in the first half of the film, we are asked to take a hard look at how "we" are constituted as urban subjects. An alienated character sits against the backdrop of a window that frames skyscrapers through the translucent blur of glass. The walls are white like a movie screen. The character sits peripheral to an interview between two doctors, but central to what the movie projects: an urbanity of alienated figures organized into the city's distribution of categories. If desire is the function into and outside of categories, the landscape is what drives this desire throughout the film. The analogy between film and landscape arrives at the sine qua non of urban pessimism. Bleakly, we are asked whether it is possible to escape this organization of everyday life, an organization that alienated subjects seem to desire.

The phrasal power of continuity that Rancière locates in the sentence-image, and that Apichatpong projects through a slow montage of life organized through symbolic imagery, illuminates an aesthetic politics of the city. In a relevant scene a Bangkok doctor, and the film's primary male protagonist, receives a visit from his girlfriend at the hospital where he works. They kiss momentarily after which she expresses her desire to move to a revitalized Chonburi where a new industrialized city is currently underconstruction. She then expresses what the narrator of both "The Next Station is..." and Calvino's Invisible Cities conveys to the reader: this new city, underconstruction, is built (or imagined) according to the changing desire of all cities. After handing him a photo album of construction photos as proof, a montage of still-images depicting the revitalized Chonburi overlay the conversation to show us what they are looking at. Most of these shots appear distant, and, in any case, devoid of human life. Toward the end of this scene, the doctor's attempt to lean forward and kiss his girlfriend is interrupted by her desire to look at the urban landscape. "Wow, you can really see my house from here."

In another scene a montage sequence of urban sculptures depicting national imagery (royal figures, Buddhism, etc.) is mixed with slow and passive shots of organized life in the hospital. Immobile sculptures are juxtaposed here with uniform-clad subjects. Some walk in single-file lines with monks following close behind them, as if leading, while others walk in groups of similar-colored uniforms. This montage sequence is juxtaposed with a proceeding montage where one worn-out doctor sits alone in the hospital's basement while another sits alone in a dimly lit office. In the analogy, the collective desire of organization is juxtaposed against the alienation of individuals who remain on the outside.

The final two scene sequences suggest an interesting juxtaposition between the interior and exterior urban landscape of Bangkok. In the first sequence, the camera enters the hospital basement. The camera's long-take pursues a slow low-angle circular pan below ceiling ventilation pipes and other varieties of equipment one might find in any factory. There is a clear 
absence of people in this room. The viewer remembers this location since it was referenced earlier in the film to suggest its strange utility as a space used to rehabilitate patients via a gradual refamiliarization with the industrial technologies of the city. It exists beneath the other levels of the hospital and, as the doctor suggests earlier, is only checked on once a week and must be considered secondary to the more significant "other cases" on the upper-levels. If the shot looks strangely familiar to film historians, it is due to its resemblance with the opening shot of Godard's Contempt (1963) where a slow pan transitions to a view that trucks into a film camera's lens. Only in Apichatpong's film, the panning camera trucks into an industrial exhaust pipe. The analogy (though it need not be the intention): whereas the viewer was encouraged to sense the presence of a thinking camera in Godard's film, Apichatpong foregrounds the banality of urban construction. His industrialized sequence foregrounds the technologies of production and also the inferior role of production in the realm of visibility, since the development of the city builds and constrains the vision of urban subjects. In the urban sequences projected in Mysterious Objects at Noon and in Syndromes and a Century, Apichatpong demonstrates that the cinema's attempt to inscribe the city is a process of selective imaging, and that a photo-album, shot sequence, or manipulation of space relies on the desire to see.

\section{Conclusion}

The similarity between cinematic modes of encountering urban life with the literary inscription outlined in the first half of this article resonates through a politics of aesthetics: a mode of assembly, of life and the division of self through functions that reproduce the city in relation to a landscape. In this way, a sentence-image produces an analogic duality tied to a landscape where film can inscribe what literature can project: a similar mode of thinking that Siriworn Kaewkan's prose poem "The Love of Crying at the Busstop" (Siriworn Kaewkan 2005: 21) so amply expresses:

Narrate the city from the
viewpoint of the self
$\begin{aligned} & \text { Narrate the self from the } \\ & \text { viewpoint of the city }\end{aligned}$

The narration of the city lies in the very inscription of it, and what I have suggested in this article is that "viewpoint" remains central to undoing any single narration. A simple narration, however, is not quite what leads a plot to develop in the contemporary literature and film treated here.

Could this analysis be conducted with similar results in the cities of other contemporary writers or filmmakers? Sure. But in some literary circles, all roads lead to the postmodern New York of Don Delillo and Paul Auster, the provincial subject's arrival in an urban Paris passed down by Stendhal, or the new globalized Asia of Haruki Murakami. There is an urgent need for contemporary literature to understand film, and there is an urgent need to look at the projection of cities in languages marginalized in global literary discourse.

This article's selection of literature and films treated above was premised upon their unique "aesthetic," their means of arranging a city that appears to a subject that sees through the frames of urban 
forms. The development of an urban problem, that is the centerpiece for the emergence of the political, calls for a return to the reality of a fictional world that usurps an aesthetic means to depict it. This is why the relationship between the sentence-images of literature and film remains a significant means of treating the perpetual development of the urban landscape. The conjoining of text and image, through either the written graphic or the moving picture, assigns poetic diversity to its underlying construction, a space that pluralizes our ability to see.

\section{References}

Balász, Béla. 2004 (1952). Theory of Film. In Film Theory and Criticism, edited by Leo Braudy and Marshall Cohen. Sixth Edition. New York: Oxford University Press.

Branigan, Edward. 2006. Projecting A Camera: Language-Games in Film Theory. New York: Routledge.

Calvino, Italo. 1974. Invisible Cities. Translated by William Weaver. New York: Harcourt.

Charungkitanan, Wanich. 1991. The Capital. In The Same Street (ซอย เดียวกัน). Bangkok: Buraphasan.

Cobley, Paul. 2001. Narrative. New York: Routledge.

Crouch, David and Charlotta Malm. 2003. Landscape Practice, Landscape Research: an Essay in Gentle Politics. In Deterritorialisations... Revisioning Landscape and Politics, edited by Mark Dorrian and Gillian Rose. London \& New York: Black Dog
Publishing Ltd.

Deleuze, Gilles. 1986. Cinema 1: The Movement-Image. Translated by Hugh Tomlinson and Barbara Habberjam. Minneapolis: University of Minnesota Press.

Elliot, Kamilla. 2003. Rethinking the Novel/Film Debate. Cambridge: Cambridge University Press.

Hutangkoon, Parithat. 2002. Flames of Love, Grounds of Regret. In

Hunt, John Dixon. 2003. Taking Place: Some Preoccupations and Politics of Landscape Study. In Deterritorialisations... Revisioning Landscape and Politics, edited by Mark Dorrian and Gillian Rose. London \& New York: Black Dog Publishing Ltd.

Kaewkan, Siriworn. 2004. A Navigator on the Deck of the Baiyoke Tower. In Narratives of a Storyteller Passed Down by a Narrator. Bangkok: Khlet Thai Printing. (Self-published)

Kaewkan, Siriworn. 2006. Our Resemblances. In The Story of Lost Ariya an Other Stories. Bangkok: Khlet Thai Printing. (Self-published)

Kaewkan, Siriworn. 2005. The Love of Crying at the Busstop. In Keep the Sorrow from the Hands of the Children. Bangkok: Khlet Thai Printing. (Self-published)

Kline, T. Jefferson. 1992. Screening the Text: Intertextuality in New Wave French Cinema. Baltimore: John Hopkins University Press. 
Korbjitti, Chart. 1993. Time. Bangkok: Khlet Thai.

Lyovarin, Win. 1999. The Lover. In Living Things Called People. Bangkok: Double Nine.

Phiphathporn, Parinya. 2005. The Next Station is... In The Sanamya Program 3: A Place in the Heart (โครงการสนาม หญ้า 3: สถานที่หนึ่งในดวงใจ). Bangkok Men Wannakam Publishing.

Rancière, Jacques. 2004. The Politics of Aesthetics. Translated by Gabriel Rockhill. New York: Continuum.

---. 2006. Film Fables. Translated by Emiliano Battista. New York: Berg Publishers.

---. 2007. The Future of the Image. Translated by Gregory Elliot. New York: Verso.

Rohdie, Sam. 2006. Montage. Manchester: Manchester University Press.

Tipyanon, Anusorn. 2003. London and the Secret In the Kiss. Bangkok: Amarin.

Yoon, Prabda. 2000. Probabilities (ความ น่าจะเป็น). Bangkok: Sudsabda Publishing.

\section{Appendix I: 3 Levels of Viewing the Victory Monument}

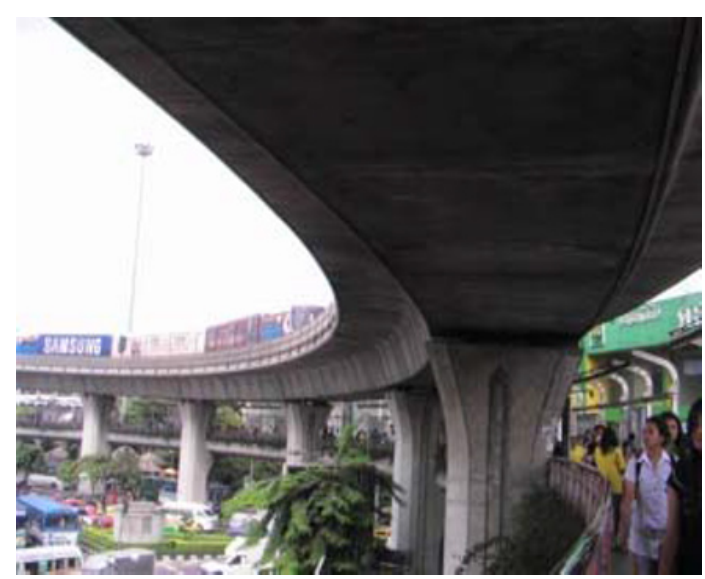

1. Skytrain Level

2. Skywalk Level

3. Bus Level 